\title{
PERAN WALI KELAS DALAM PEMBINAAN DISIPLIN BELAJAR DI PONDOK PESANTREN ANWARUL HASANIYYAH (ANWAHA) KABUPATEN TABALONG
}

\author{
Syahrani \\ Sekolah Tinggi Agama Islam (STAI) Rasyidiyah Khalidiyah Amuntai, Indonesia \\ syahranias481@gmail.com
}

\begin{abstract}
Abstrak
Pondok pesantren adalah Lembaga pendidikan bercirikan Islam yang sudah menjadi identitas pendidikan Islam di Indonesia. Keberadaannya tidak hanya menjadi pendidikan alternatif di samping Lembaga pendidikan negeri, akan tetapi sudah menjadi pilihan utama bagi orangtua untuk menjadi menitipkan anakanaknya agar bisa belajar agama Islam dengan lebih baik. Tujuan penelitian ini untuk mendeskripsikan peran wali kelas di pondok pesantren Anwarul Hasaniyah dalam mendidik kedisiplinan santri di dalam dan luar kelas. Penelitian ini mengunakan metode kualitatif dengan jenis penelitian narrative research dan tekhnik pengumpulan data dengan observasi terlibat serta wawacara terstruktur.

Peran wali kelas dalam pembinaan disiplin belajar di Pondok Pesantren Anwarul Hasil penelitian ini menunjukkan bahwa peran wali kelas di pondok pesantren Anwarul Hasaniyyah (Anwaha) Kabupaten Tabalong diwujudkan dengan pembuatan tata tertib kelas oleh wali kelas berdasarkan musyawarah dengan siswa pada kelas yang dibina, melakukan pengawasan oleh wali kelas secara langsung dan laporan dari siswa pada kelas yang dibina dan bekerjasama dengan asatidz dalam membina siswa.
\end{abstract}

Kata Kunci: Wali Kelas, Disiplin Belajar, Anwaha

\section{PENDAHULUAN}

Wali kelas merupakan gelar bagi guru yang diberi amanah untuk membina suatu kelas pada instansi pendidikan di tingkat dasar (SD sederajat) sampai tingkat atas (SLTA sederajat), sebagai wali kelas hendaknya mampu memimpin kelas yang menjadi tenggungjawabnya, itulah satu satu peran penting wali kelas dalam pembelajaran. ${ }^{1}$ Dalam hal ini Allah SWT berfirman dalam surah Shad ayat 26 yang berbunyi:

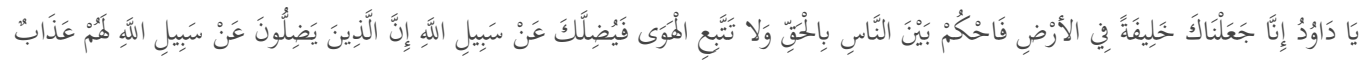

$$
\begin{aligned}
& \text { شَدِيدُ بِمَا نَسُوا يَوْمَ الحِسَِابِ }
\end{aligned}
$$

Ayat di atas menegaskan bahwa sebagai pemimpin harus mampu menegakkan kebenaran di wilayahnya, begitu juga halnya wali kelas harus mampu menangani permasalahan yang terjadi

\footnotetext{
${ }^{1}$ Mustika, Zahara. "Pentingnya Peranan Wali Kelas Dalam Pembelajaran." Intelektualita 3, no. 1 (2015): h. 65-78

Al Qalam: Jurnal Ilmiah Keagamaan dan Kemasyarakatan Vol. 16, No. 1 Januari - Juni 2022
} 
Syahrani : Peran Wali Kelas Dalam Pembinaan Displin Belajar di Pondok Pesantren Anwarul Hasaniyan (ANWAHA) Kabupaten Tabalong

di kelasnya bahkan diharapkan mampu menjadi teladan bagi siswa di kelas yang dibinanya, untuk itulah perlunya landasan qurani dalam manajemen kelas. ${ }^{2}$

Hal ini senada dengan pernyataan Bagus Herdananto dalam bukunya yang berjudul Menjadi Guru Bermoral Profesional bahwa wali kelas hendaknya adalah sosok yang dapat menjadi teladan dan memberi kebaikan bagi seseorang maupun semua orang. ${ }^{3}$

Uraian di atas menjelaskan bahwa sebagai wali kelas hendaknya mampu menjadi teladan bagi kelas yang dibina dan mampu memberikan kebaikan kepada siswa dengan menegakkan aturan, tapi bukan berarti keras, kejam dan tidak ada kebijaksanaan, sebab harus juga wali kelas bertindak humanis dalam membina santri. ${ }^{4}$

Dewasa ini masih banyak guru yang tidak mampu dan sangat kesulitan dalam menguasai kelas, peserta didik yang gaduh sering membuat guru kewalahan mengatasinya. Dengan begitu, guru mengambil jalan pintas seraya mengabaikan pedagogik, berteriak dengan suara keras di dalam kelas dan bahkan berkali-kali memukul meja, menambah suasana kelas semakin ramai dan tidak kondusif. Jika wali kelas membiasakan berteriak di dalam kelas, akibatnya suaranya tidak akan didengar lagi oleh siswa, tenggorokan akan sakit karenanya bahkan suaranya akan serak.

Fenomena kelas yang gaduh memang menjadi momok yang biasa ditemukan diberbagai sekolah. Saat suasana kelas seperti itu maka wali kelas perlu bertindak, sebab wali kelas merupakan orang yang paling bertanggung jawab terhadap kondisi kelas yang menjadi binaannya.

Kegaduhan suasana kelas kadang penyebab munculnya beragam, ada yang berbicara yang tidak penting dengan teman dan kadang juga muncul karena cara siswa berbicara pada waktu yang bersamaan. Suasana kelas yang gaduh memberikan dampak yang buruk terhadap jalannya proses pembelajaran, maka kondisi kelas yang seperti ini hendaknya dapat ditangani oleh wali kelas dengan secepat mungkin, sebab semua tenaga kependidikan, terlebih wali kelas yang paling bertanggung jawab terhadap kondisi kelas. Wali kelas, siswa dan dewan guru merupakan orang yang paling mendambakan suasana kelas yang tertib dan tenang. Suasana kelas yang tenang tidak hanya diharapkan pada saat wali kelas berada di kelas itu saja, tetapi juga suasana kelas yang kondusif sangat diharapkan juga terwujud saat guru mata pelajaran lain sedang mengajar.

Dalam rangka menciptakan suasana kelas yang kondusif, Sudarwan Danim menyatakan bahwa wali kelas hendaknya membantu siswa dalam mempelajari tingkah laku yang diharapkan

\footnotetext{
${ }^{2}$ Syahrani, Syahrani. "Manajemen Pendidikan Dengan Literatur Qur'an." Darul Ulum: Jurnal Ilmiah Keagamaan, Pendidikan dan Kemasyarakatan (2019): 191-203.

${ }^{3}$ Bagus Herdananto, Menjadi Guru Bermoral Profesional, (Yogyakarta: Kreasi Wacana, 2009), h.

${ }^{4}$ Syahrani, Syahrani. "Manajemen kelas yang humanis." al-risalah 14, no. 1 (2018): 57-74.

Al Qalam: Jurnal Ilmiah Keagamaan dan Kemasyarakatan Vol. 16, No. 1 Januari - Juni 2022
} 
Syahrani : Peran Wali Kelas Dalam Pembinaan Displin Belajar di Pondok Pesantren Anwarul Hasaniyan (ANWAHA) Kabupaten Tabalong

melalui prinsip (reinforcement) yang dilakukan secara kontinu, adakalanya hal itu harus dilakukan dengan format mengkondisikan (conditioning) hingga siswa menjadi terbiasa dengan perilaku yang diharapkan dari yang mulnya cenderung mengalamai deviasi. ${ }^{5}$

Uraian di atas menjelaskan bahwa wali kelas bertanggung jawab dalam membantu siswa secara kontinu dalam membenarkan perilaku yang tidak layak dengan cara mengkodisikan siswa hingga terbiasa bersikap tertib. Peran wali kelas sangat sentral terutama dalam hal membina dan mengembangkan suasana atau iklim sosioemosional kelas yang positif melalui pernumbuhan hubungan interpersonal yang sehat dan dinamis, penuh kasih sayang dan tanpa prasangka.

Ada banyak tips yang dapat lakukan dalam menciptakan suasana kelas yang semula gaduh menjadi kondusif, yang semula ramai menjadi tenang, dan yang semula ribut menjadi hening. Mansyur dalam bukunya yang berjudul Suara Daerah menyebutkan cara menciptakan suasana kelas menjadi kondusif sebagai berikut:

1. Menatap dengan tajam kepada seluruh siswa yang hadir

2. Senyum kepada siswa

3. Pengaturan suara

4. Seni bahasa tubuh ${ }^{6}$

Pendapat di atas menyebutkan bahwa dalam menciptakan suasana kelas yang kondusif bisa diwujudkan dengan menatap tajam, memberikan senyuman kepada siswa yang terlihat membuat kegaduhan, mengatur suara dan menggunakan bahasa tubuh.

Menatap dengan tajam kepada seluruh santri yang hadir. Pandangan yang tajam khususnya kepada santri yang sedang berbicara dengan temannya, biasanya yang bersangkutan akan segera duduk manis dan mengakhiri obrolannya, santri tersebut berarti sudah dapat menangkap sinyal dan keinginan ustadz, supaya mereka tidak gaduh di kelas. Setelah itu, ustadz baru boleh berkedip. Kedipan mata yang diberikan kepada anak tersebut, sebagai isyarat bahwa ustadz tidak marah dan menghargai perubahan sikapnya. Demikian pula sebaliknya, bahwa santri masih menghargai dan segan kepada ustadz. Menghukum badan karena marah terhadap perilaku santri, mencubit lengan santri, memukul, memplototi, dan menatap mata tanpa berkedip, dampaknya sangat patal bagi peserta didik. Untuk itu, hindari hukuman badan karena termasuk melanggar hak-hak santri dan bisa jadi bahan tuntutan hukum. Wali kelas harusnya berusaha meerubah keadaan menjadi positif untuk membawa santri menuju pembelajaran yang menyenangkan dan menantang, sehingga mereka dapat mengembangkan kompetensinya. Jika peserta didik merasa bosan dalam mengikuti proses pembelajaran, mereka akan berontak dan

\footnotetext{
${ }^{5}$ Sudarwan Danim, Visi Baru Manajemen Sekolah, (Jakarta: Bumi Aksara, 2008), h. 42

${ }^{6}$ Mansyur, Suara Daerah, (Bandung: Grafindo Media Pratama, 2009), h. 27

Al Qalam: Jurnal Ilmiah Keagamaan dan Kemasyarakatan Vol. 16, No. 1 Januari - Juni 2022
} 
Syahrani : Peran Wali Kelas Dalam Pembinaan Displin Belajar di Pondok Pesantren Anwarul Hasaniyan (ANWAHA) Kabupaten Tabalong

berulah, terlebih jika banyak pekerjaan rumah (tugas rumah) yang memberatkan, pasti merasa cemas. Percayalah, jika mereka merasa senang dan terlibat langsung di dalamnya proses pembelajaran pasti mereka mau belajar dan melakoninya dengan baik dan penuh kesadaran.

Saat terlihat beberapa siswa tidak memperhatikan pelajaran yang sedang dipaparkan, sebaiknya segera menegur siswa tersebut, sehingga tidak mengganggu prosesi pembelajaran. Ketika menegur siswa bukan dengan cara membentak atau memarahinya, tetapi dengan melemparkan senyum kepada mereka. Senyum yang diberikan seolah-olah teguran untuk mengehentikan keributan. Senyum yang diberikan dapat menggugah dan mengubah perilaku peserta didik, bahkan siswa akan segera meresponnya, pandangan siswa akan segera tertuju kepada guru, seraya memperhatikan pelajaran yang sedang diterangkan. Senyum yang hangat akan memancarkan kesan bahwa anda tergolong guru yang gaul dan ramah. Namun, penulis tidak bermaksud agar anda terus senyum sepanjang hari ketika di kelas, karena justru anda akan terlihat menjadi aneh, yang jelas wajah masam, pasti tidak menyenangkan untuk dilihat dan tidak boleh dipertahankan, khususnya ketika pembelajaran berlangsung di kelas bertatap muka dengan peserta didik.

Budayakan agar tidak menerangkan pelajaran jika masih ada siswa yang berbicara dengan temannya. Obrolan peserta didik di kelas ketika pembelajaran berlangsung, sebenarnya dapat di atasi dengan cara merendahkan atau memelankan suara. Ketika memulai mengajar saat itu yang terdengar di dalam kelas hanyalah suara dengungan pelan akibat siswa yang ngobrol. kondisi seperti ini, guru cenderung menyikapinya dengan meningkatkan volume suaranya untuk didengar oleh mereka, namun pada kenyataannya, semakin tinggi volume suara anda, suara dengungan tersebut akan terdengar semakin keras . sementara itu, anda pun tetap berlanjut menerangkan pelajaran dengan berteriak-teriak. cara seperti ini tidak akan mampu mengubah suasana kelas yang gaduh menjadi tenang. Sebaiknya pelankan suara anda karena dengan suara yang pelan peserta didik akan berhenti berbicara, selanjutnya mereka akan berusaha mau mendengar dan memperhatikan suara anda, bahkan diantara mereka akan menyuruh teman-temannya untuk tidak mengobrol.

Pada awal minggu-minggu pertama masuk sekolah, sebaiknya wali kelas dapat membiasakan peserta didik dengan melakukan bahasa tubuh tertentu, guna menjaga kesehatan dan menghemat energi seperti ketika ada suara gaduh di kelas segera tempelkan telunjuk di bibir, sebagai perhatian supaya mereka tenang. Mengajar adalah seni, karenanya tidak mungkin sterio tape, melainkan sesuatu yang bisa dan harus diexplorasi. Guru harus bisa menciptakan pembelajaran sebagai sesuatu yang menarik bagi peserta didiknya. Dengan begitu, mereka akan senang belajar. Guru, seharusnya memikirkan bagaimana menciptakan sekolah menjadi sebuah

Al Qalam: Jurnal Ilmiah Keagamaan dan Kemasyarakatan Vol. 16, No. 1 Januari - Juni 2022 
Syahrani : Peran Wali Kelas Dalam Pembinaan Displin Belajar di Pondok Pesantren Anwarul Hasaniyan (ANWAHA) Kabupaten Tabalong

taman yang indah dan nyaman sebagai tempat belajar, dengan gaya dan model pembelajaran yang menyenangkan, tentunya.

Ketika memulai pelajaran coba lakukan bertepuk tangan, kegiatan ini peserta didik menganggapnya hanya sebuah permainan belaka, dan kelihatannya memang demikian adanya, yang penting adalah hasil akhirnya kelas menjadi tenang dan tidak gaduh. Guru seharusnya pembelajar sepanjang hayat. Guru jangan merasa cukup dengan ilmu yang telah dimiliki dan dikuasainya, tetapi harus belajar dan mengaktulisasi diri secara terus menerus. Faktor utama dalam penguasaan kelas dan mengembangkan pembelajaran yang menyenangkan, bukan hanya dana semata, melainkan kemauan yang kuat dan kreativitas guru.

Apalagi tujuan Pendidikan Nasional yang termuat dalam Undang-Undang RI No. 20 Tahun 2003 Bab II Pasal 3 tentang Sistem Pendidikan Nasional ditegaskan bahwa: Pendidikan Nasional berfungsi untuk mengembangkan kemampuan dan membentuk watak serta peradaban bangsa yang bermartabat dalam rangka mencerdaskan kehidupan bangsa, bertujuan untuk berkembangnya potensi peserta didik agar menjadi manusia yang beriman dan bertakwa kepada TuhanYang Maha Esa, berakhlak mulia, sehat, berilmu, cakap, kreatif, mandiri, dan menjadi warga negara yang demokratis serta bertanggung jawab. ${ }^{7}$

Uraian di atas menyebutkan bahwa pada dasarnya pendidikan bertujuan untuk membentuk watak dan peradaban manusia yang bermartabat cerdas serta berakhlak mulia. Berdasarkan latar belakang tersebut, peneliti tertarik untuk mengkaji lebih mendalam tentang peran wali kelas dalam pembinaan disiplin belajar di Pondok Pesntren Anwarul Hasaniyyah (Anwaha) Kabupaten Tabalong

\section{METODE PENELITIAN}

Pendekatan yang digunakan adalah pendekatan kualitatif, yaitu penelitian yang datanya berupa kalimat yang berasal dari wawancara, catatan laporan, dokumen, dan penelitian mengutamakan pendeskripsian (interprestasi) secara analisis terhadap peristiwa. Pendekatan kualitatif dipilih karena mampu mendiskripsikan makna peristiwa secara detail dan memudahkan dalam identifikasi tipe informasi dalam pendeskripsian fenomena. Adapun jenis penelitian yang dipilih berupa studi kasus. Hal ini dimaksud agar semua fenomena di lapangan terungkap secara nyata dan akurat sebagaimana hasil temuan selama peneliti terjun langsung ke lokasi penelitian.

Lokasi penelitian adalah Pondok Pesantren Anwarul Hasaniyyah (Anwaha), informan dewan asatidz, operator, masyarakat dan wali kelas Anwaha sebagai subjek penelitian.

\footnotetext{
${ }^{7}$ Direktorat Jenderal Pendidikan Islam,Undang-Undang dan Peraturan Pemerintah RI, (Jakarta: Departemen Agama, 2006), h. 8
}

Al Qalam: Jurnal Ilmiah Keagamaan dan Kemasyarakatan Vol. 16, No. 1 Januari - Juni 2022 
Syahrani : Peran Wali Kelas Dalam Pembinaan Displin Belajar di Pondok Pesantren Anwarul Hasaniyan (ANWAHA) Kabupaten Tabalong

Teknik yang digunakan dalam pengumpulan data berupa observasi, wawancara dan telaah dokumen, sedangkan teknik dalam pengolahan dan analisis data berupa reduksi data, display data dan verifikasi data. Penggunaan teknik tersebut dan analisis digunakan secara bersamaan, sedangkan dalam pengujian keabsahan data menggunakan teknik kredibilitas, transferabilitas, dipendabilitas, dan konfirmabilitas.

\section{HASIL DAN PEMBAHASAN}

Disiplin belajar akan sangat berpengaruh terhadap prestasi belajar santri, ${ }^{8}$ bukan sekedar berpengaruh, tapi berpeluang membuat prestasi belajar santri jadi lebih meningkat dan lebih baik, ${ }^{9}$ bahkan ketika disiplin belajar tercipta, justru menjadi wahana motivasi bagi santri lainnya untuk berpacu dalam meningkatkan prestasi belajarnya, ${ }^{10}$ karena itu wali kelas harus menunjukkan perannya dalam pembinaan disiplin belajar. Perihal peran wali kelas dalam pembinaan disiplin belajar di Pondok Pesantren Anwarul Hasaniyyah (Anwaha) Kabupaten Tabalong, meliputi:

a. Pembuatan Tata Tertib Kelas

Pembuatan tata tertib kelas awalnya untuk menciptakan disiplin belajar dan secara tidak langsung sebenarnya sebagai langkah dalam membentuk kepribadian santri. ${ }^{11}$ Dengan tata tertib kelas diharapkan mempercepat terwujudnya disiplin belajar. ${ }^{12}$ Di samping tata tertib sekolah yang sudah berlaku di sekolah, tata tertib kelas juga harus dibuat demi kelengkapan administrasi kelas dengan tujuan untuk lebih menertibkan dan mengaktifkan siswa dalam kegiatan pembelajaran di kelas. Tata tertib kelas yang sudah dibuat, memang harus dilaksanakan, namun juga perlu dievaluasi tata tertib tersebut agar bermanfaat secara maksimal dalam mencapai tujuan dibuatnya tata tertib kelas. ${ }^{13}$

\footnotetext{
${ }^{8}$ Matussolikhah, Rindiani, and Brillian Rosy. "Pengaruh Disiplin Belajar dan Gaya Belajar terhadap Hasil Belajar Siswa dalam Pembelajaran Daring di Masa Pandemi Covid-19." Prima Magistra: Jurnal Ilmiah Kependidikan 2, no. 2 (2021): 225-236.

${ }^{9}$ Handayani, Eka Selvi, and Hani Subakti. "Pengaruh Disiplin Belajar terhadap Hasil Belajar Bahasa Indonesia di Sekolah Dasar." Jurnal Basicedu 5, no. 1 (2021): 151-164.

${ }^{10}$ Liubana, Alfred, and Durinda Puspasari. "Analisis Pengaruh Penggunaan E-Learning dengan Google Classroom dan Disiplin Belajar terhadap Motivasi Belajar Mahasiswa Brothers and Sisters House Kota Surabaya pada Masa Pandemi Covid-19." Jurnal Kependidikan: Jurnal Hasil Penelitian dan Kajian Kepustakaan di Bidang Pendidikan, Pengajaran dan Pembelajaran 7, no. 2 (2021): 417-427.

${ }^{11}$ Laili, Suci, Bambang Budi Utomo, and Thomy Sastra Atmaja. "Penerapan Tata Tertib Sekolah Guna Membentuk Kepribadian Siswa Kelas X Ips Sman 5 Pontianak." Jurnal Pendidikan dan Pembelajaran Khatulistiwa 10, no. 6. (2021): 1-8.

${ }^{12}$ Via, Iren, and Ariani Tandi Padang. "Pentingnya Tata Tertib Untuk Membentuk Disiplin Belajar Siswa SMP." Kumpulan Artikel Ilmiah Rumpun Ekonomi dan Ilmu Sosial 1, no. 1 (2021): 78-94.

${ }^{13}$ Rochanah, Siti. "Upaya Meningkatkan Kemampuan Menganalisa Tata Tertib di Sekolah Melalui Penerapan Metode Pembelajaran Round Table Pada Siswa Kelas 2." Jurnal Education and Development 9, no. 1 (2021): 405-405.
}

Al Qalam: Jurnal Ilmiah Keagamaan dan Kemasyarakatan Vol. 16, No. 1 Januari - Juni 2022 
Syahrani : Peran Wali Kelas Dalam Pembinaan Displin Belajar di Pondok Pesantren Anwarul Hasaniyan (ANWAHA) Kabupaten Tabalong

Berdasarkan data yang penulis dapat dari hasil wawancara diketahui bahwa tata tertib di kelas telah dibuat dan berlaku terhadap siswa yang berada di kelas tersebut demi suksesnya kegiatan pembelajaran.

Wali kelas telah menempel tata tertib kelas yang harus dipatuhi demi suksesnya kegiatan pembelajaran dan apabila ada yang melanggar tata tertib tersebut akan diberikan sanksi untuk memberikan efek jera kepada yang telah melanggar dan peringatan bagi yang lainnya. Sanksi yang diberikan guru bisa berupa denda atau mengganti barang yang telah dirusak, membersihkan ruang kelas, membersihkan kamar kecil dan seberat-beratnya bisa diskorsing atau dikeluarkan dari sekolah.

Berdasarkan observasi yang penulis saksikan pada hari Senin 16 Nopember 2021, setiap kelas memang terpajang tata tertib kelas, pada kelas I terletak di depan kelas tepat di samping kanan papan tulis, tata tertib kelas di kelas II terletak di samping kanan meja guru, dan di kelas III sampai kelas VI, tata tertib kelas terletak di depan kelas tepatnya di samping kiri pintu kelas, sebab tata tertib kelas merupakan sebuah sistem aturan yang telah dipertimbangkan dan dibentuk lewat suatu kesepakatan antara guru dan siswa dan bisa juga hanya ditetapkan oleh pihak sekolah karena dianggap aturan yang dibuat masih standar dan tidak terlalu memberatkan siswa karena bertujuan untuk ketertiban kelas semata. Hal ini menunjukkan bahwa tata tertib kelas merupakan aturan yang dibentuk lewat musyawarah antara guru dan siswa atau dibuat oleh pihak sekolah yang bertujuan untuk ketertiban sekolah, inilah langkah awal dari pola pembinaan disiplin belajar di Pondok Pesantren Anwarul Hasaniyyah (Anwaha) Kabupaten Tabalong dalam membina disiplin belajar santri. ${ }^{14}$

Sesuai realita yang penulis temukan di lapangan dan berdasarkan teori pakar pendidikan yang sudah sesuai dengan dengan kenyataan, maka tata tertib kelas di Pondok Pesantren Anwarul Hasaniyyahdapat dikatakan telah dibuat.

b. Melakukan pengawasan

Pengawasan terhadap siswa sangatlah penting guna terjaganya suasana pembelajaran yang kondusif, sebab kenyataannya banyak siswa yang sulit diatur, bahkan mungkin ada beberapa guru yang tidak sanggup mengendalikan suasa kelas, meskipun diberi ancaman akan dilaporkaan dengan wali kelas. Hal ini senada dengan firman Allah SWT dalam surah Al-Kahfi ayat 54 yang berbunyi:

${ }^{14}$ Ningrum, Widya Agustin, and Miftachul Choiri. "Pentingnya Pentingnya Pola Komunikasi Orang Tua dan Wali Kelas dalam Membangkitkan Motivasi Belajar Siswa melalui Kegiatan Paguyuban." AL THIFL 1, no. 1 (2021): 46-52.

Al Qalam: Jurnal Ilmiah Keagamaan dan Kemasyarakatan Vol. 16, No. 1 Januari - Juni 2022 
Syahrani : Peran Wali Kelas Dalam Pembinaan Displin Belajar di Pondok Pesantren Anwarul Hasaniyan (ANWAHA) Kabupaten Tabalong

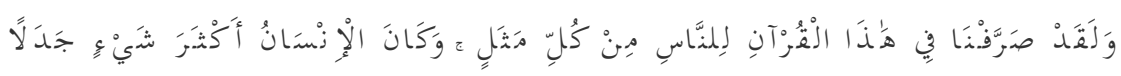

Ayat tersebut menjelaskan bahwa manusia merupakan makhluk yang paling banyak membantah dan melanggar aturan Allah, padahal mereka menyadari manfaat dan akibat dari melanggar aturan Allah SWT tersebut, karena Allah SWT telah memberikan berbagai macam perumpamaan agar manusia menyadari dan melihat akibatnya, namun ternyata manusia tetap membantah dan melanggar larangan Allah SWT

Sesuai hasil wawancara, wali kelas di Pondok Pesantren Anwarul Hasaniyyah (Anwaha) mengaku telah melakukan monitoring terhadap kelas yang menjadi binaannya. Cara monitoring yang dilakukan wali kelas di Pondok Pesantren Anwarul Hasaniyyah (Anwaha) dengan mengontrol langsung dan minta laporan dari seksi keamanan serta laporan dari ketua kelas.

Asatidz di Pondok Pesantren Anwarul Hasaniyyah (Anwaha) memberikan kesaksian tentang adanya pengontrolan dari wali kelas terhadap kelas yang menjadi tanggung jawab wali kelas tersebut. Kenyataannya pada tanggal 17 Nopember 2021 beberapa wali kelas telah melakukan pengawasan kelasnya.

Pengamatan kepada santri dilakukan secara periodik, ketika ada santri yang terlihat kurang disiplin dalam belajar, maka wali kelas segera mendekati santri dengan tenang dan penuh wibawa dan menjalin komunikasi agar santri tersebut bercerita sendiri mengenai sikapnya yang kurang wajar tersebut, itulah wujud kesiagaan wali kelas dalam membina kedisiplinan belajar santri. ${ }^{15}$

Kenyataannya wali kelas telah melakukan monitoring sebagaimana yang disebutka teori di atas, maka cara wali kelas dalam monitoring siswa dapat dikatakan sudah bagus.

c. Bekerjasama dengan asatidz dalam membina santri

Dalam membina santri perlu kerja sama antar dewan guru, sehingga siswa benarbenar merasakan kesan adanya kerja sama dewan guru dalam membina mereka, maka dewan guru selalu berkoordinasi satu sama lain sebagai wujud kerjasama dalam membina siswa, akan tetapi demi menjaga nama baik hubungan kekerabatan, jadi jika asatidz yang memiliki hubungan kekerabatan dengan siswa yang melanggar, ${ }^{16}$ maka penegakkan aturan diserahkan kepada wali kelas dan jika masih ada hubungan kekerabatan maka dilempar lagi kepada

\footnotetext{
${ }^{15}$ Shaleha, Radhia, and Auladina Shalihah. "Analisis Kesiapan Siswa Filial Dambung Raya Dalam Mengikuti Analisis Nasional Berbasis Komputer Di Sman 1 Bintang Ara Kabupaten Tabalong." Joel: Journal of Educational and Language Research 1, no. 3 (2021): 221-234.

${ }^{16}$ Agustang, Andi. "Peran Wali Kelas Dalam Penyelesaian Konflik Antar Siswa Di Sma Negeri 1 Pinrang." Jurnal Sosialisasi: Jurnal Hasil Pemikiran, Penelitian dan Pengembangan Keilmuan Sosiologi Pendidikan (2018): 12-16.
}

Al Qalam: Jurnal Ilmiah Keagamaan dan Kemasyarakatan Vol. 16, No. 1 Januari - Juni 2022 
Syahrani : Peran Wali Kelas Dalam Pembinaan Displin Belajar di Pondok Pesantren Anwarul Hasaniyan (ANWAHA) Kabupaten Tabalong

kepala madrasah, agar pembinaan santri lebih diutamakan dan mengenyampingkan hubungan kekerabatan. ${ }^{17}$

Selama observasi di Pondok Pesantren Anwarul Hasaniyyah (Anwaha), penulis menyaksikan dewan guru dan wali kelas memang saling berkoordinasi dalam membina siswa, sebab penulis mendengar langsung wali kelas III meminta bantuan kepada salah satu asatidz agar sesekali menjenguk kelas III yang lagi latihan akhir pokok bahasan, sebab saat itu wali kelas III masih ada yang diketik di ruang Tata Usaha.

Jika sebagian guru saja yang menegakkan aturan, sedangkan yang lain acuh terhadap pelanggaran aturan sekolah, tentunya tidak perlu berharap banyak tata tertib sekolah bisa tegak sendirinya, apalagi berharap terlihatnya disiplin belajar santri, dalam ini Allah SWT berfirman dalam surah Al-Maidah ayat 2 yang berbunyi:

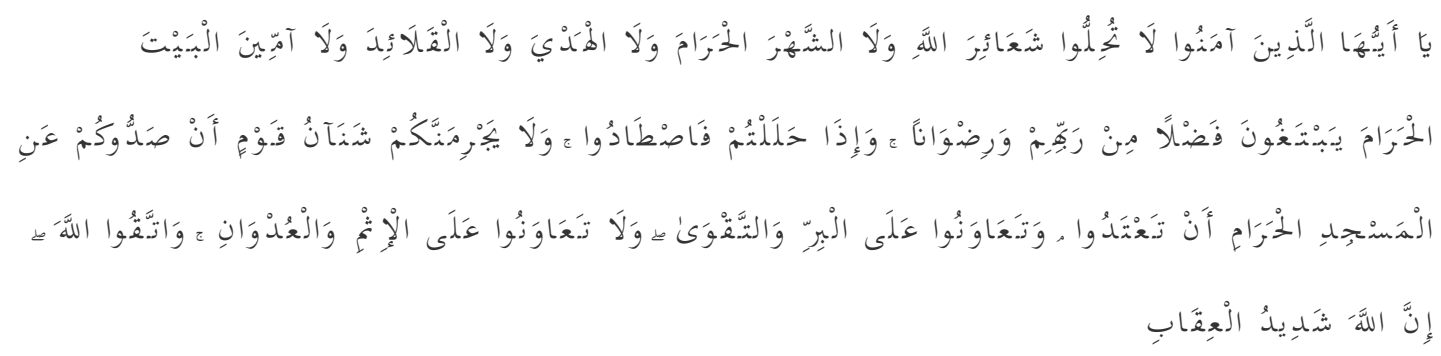

Ayat tersebut memerintahkan agar saling bekerja sama dalam kebaikan dan tidak bekerja sama dalam keburukan yang dibuktikan dengan sama-sama menjalankan tata tertib sekolah dan menegakkannya ketika terjadi pelanggaran terhadap tata tertib tersebut, sehingga manajemen kelas lebih maksimal dan harapannya disiplin belajar santri jadi lebih terbina. ${ }^{18}$

\section{KESIMPULAN}

Peran wali kelas dalam pembinaan disiplin belajar di Pondok Pesantren Anwarul Hasaniyyah (Anwaha) Kabupaten Tabalong dilakukan dengan pembuatan tata tertib kelas, melakukan pengawasan dan bekerjasama dengan asatidz dalam membina santri.

\section{DAFTAR PUSTAKA}

Agustang, Andi. "Peran Wali Kelas Dalam Penyelesaian Konflik Antar Siswa Di Sma Negeri 1 Pinrang." Jurnal Sosialisasi: Jurnal Hasil Pemikiran, Penelitian dan Pengembangan Keilmuan Sosiologi Pendidikan (2018): 12-16.

Bagus Herdananto, Menjadi Guru Bermoral Profesional, Yogyakarta: Kreasi Wacana, 2009

${ }^{17}$ Oualeng, Henderina, and Sundari Hamid. "Peran Orang Tua Dan Wali Kelas Dalam Pembentukan Afektif Siswa Di Sd Negeri Nusa Harapan Permai Kota Makassar." Bosowa Journal of Education 1, no. 2 (2021): 76-80.

${ }^{18}$ Rosanti, Atik. "Manajemen Kelas Sebagai Pembentuk Karakter Peserta Didik Di SMK Al Ihya Selajambe Kabupaten Kuningan." Syntax Literate; Jurnal Ilmiah Indonesia 6, no. 4 (2021): 1596-1605.

Al Qalam: Jurnal Ilmiah Keagamaan dan Kemasyarakatan Vol. 16, No. 1 Januari - Juni 2022 
Syahrani : Peran Wali Kelas Dalam Pembinaan Displin Belajar di Pondok Pesantren Anwarul Hasaniyan (ANWAHA) Kabupaten Tabalong

Danim, Sudarwan, Visi Baru Manajemen Sekolah, Jakarta: Bumi Aksara, 2008

Departemen Agama RI, Al-Quran dan Terjemahnya, Bandung: CV Penerbit J-Art, 2004

Direktorat Jenderal Pendidikan Islam,Undang-Undang dan Peraturan Pemerintah RI, Jakarta: Departemen Agama, 2006

Handayani, Eka Selvi, and Hani Subakti. "Pengaruh Disiplin Belajar terhadap Hasil Belajar Bahasa Indonesia di Sekolah Dasar." Jurnal Basicedu 5, no. 1 (2021): 151-164.

Laili, Suci, Bambang Budi Utomo, and Thomy Sastra Atmaja. "Penerapan Tata Tertib Sekolah Guna Membentuk Kepribadian Siswa Kelas X Ips Sman 5 Pontianak." Jurnal Pendidikan dan Pembelajaran Khatulistiwa 10, no. 6. (2021): 1-8.

Liubana, Alfred, and Durinda Puspasari. "Analisis Pengaruh Penggunaan E-Learning dengan Google Classroom dan Disiplin Belajar terhadap Motivasi Belajar Mahasiswa Brothers and Sisters House Kota Surabaya pada Masa Pandemi Covid-19." Jurnal Kependidikan: Jurnal Hasil Penelitian dan Kajian Kepustakaan di Bidang Pendidikan, Pengajaran dan Pembelajaran 7, no. 2 (2021): 417-427.

Mansyur, Suara Daerah, Bandung: Grafindo Media Pratama, 2009

Matussolikhah, Rindiani, and Brillian Rosy. "Pengaruh Disiplin Belajar dan Gaya Belajar terhadap Hasil Belajar Siswa dalam Pembelajaran Daring di Masa Pandemi Covid-19." Prima Magistra: Jurnal Ilmiah Kependidikan 2, no. 2 (2021): 225-236.

Ningrum, Widya Agustin, and Miftachul Choiri. "Pentingnya Pentingnya Pola Komunikasi Orang Tua dan Wali Kelas dalam Membangkitkan Motivasi Belajar Siswa melalui Kegiatan Paguyuban." AL THIFL 1, no. 1 (2021): 46-52.

Oualeng, Henderina, and Sundari Hamid. "Peran Orang Tua Dan Wali Kelas Dalam Pembentukan Afektif Siswa Di Sd Negeri Nusa Harapan Permai Kota Makassar." Bosowa Journal of Education 1, no. 2 (2021): 76-80.

Rochanah, Siti. "Upaya Meningkatkan Kemampuan Menganalisa Tata Tertib di Sekolah Melalui Penerapan Metode Pembelajaran Round Table Pada Siswa Kelas 2." Jurnal Education and Development 9, no. 1 (2021): 405-405.

Rosanti, Atik. "Manajemen Kelas Sebagai Pembentuk Karakter Peserta Didik Di SMK Al Ihya Selajambe Kabupaten Kuningan." Syntax Literate; Jurnal Ilmiah Indonesia 6, no. 4 (2021): 1596-1605.

Shaleha, Radhia, and Auladina Shalihah. "Analisis Kesiapan Siswa Filial Dambung Raya Dalam Mengikuti Analisis Nasional Berbasis Komputer Di Sman 1 Bintang Ara Kabupaten Tabalong." Joel: Journal of Educational and Language Research 1, no. 3 (2021): 221234.

Syahrani, Syahrani. "Manajemen kelas yang humanis." al-risalah 14, no. 1 (2018): 57-74.

Syahrani, Syahrani. "Manajemen Pendidikan Dengan Literatur Qur'an." Darul Ulum: Jurnal Ilmiah Keagamaan, Pendidikan dan Kemasyarakatan (2019): 191-203.

Via, Iren, and Ariani Tandi Padang. "Pentingnya Tata Tertib Untuk Membentuk Disiplin Belajar Siswa SMP." Kumpulan Artikel Ilmiah Rumpun Ekonomi dan Ilmu Sosial 1, no. 1 (2021): 78-94.

Al Qalam: Jurnal Ilmiah Keagamaan dan Kemasyarakatan Vol. 16, No. 1

Januari - Juni 2022 